\author{
https://doi.org/10.18485/primling.2020.21.2 \\ 37.018.43:004.9 \\ Originalni naučni rad \\ Primljen: 22.07.2020 \\ Prihvaćen: 23.09.2020
}

\author{
Dragana Ilić \\ "Genius" Education Centre
}

Valentina Bošković Marković

Singidunum University, Faculty of Business

\title{
TEACHING IN ONLINE CLASSROOM FROM THE PERSPECTIVE OF ENGLISH LANGUAGE TEACHERS
}

\begin{abstract}
The purpose of this paper is to analyze whether the replacement of traditional classrooms with online classrooms affects learning English at university level, especially from English language teachers' perspective. The paper offers an overview of the characteristics of traditional and online classroom, along with the advantages and disadvantages of both approaches, with special reference to the role of teachers. The research presented in this paper refers to the analysis of an online questionnaire in order to determine whether English language teachers believe that online classrooms can really replace traditional classrooms even after the outbreak of COVID-19.
\end{abstract} pandemic

Keywords: traditional classroom, online teaching, the English language,

\section{INTRODUCTION}

Technology and the internet are undoubtedly the biggest contributors to the growth of the English language in the 21st century, with the phrases 'e-Learning', 'Technology in Education' and ICT that have become the buzz words in every academic setting (Chhabra, 2012: 2229). Moreover, one of the sectors which is highly affected by the worldwide pandemic of COVID-19 is most certainly higher education area. According to UNESCO, 'On 1 April 2020, schools and higher education institutions 
were closed in 185 countries, affecting 1542412000 learners, which constitute $89.4 \%$ of total enrolled learners. At the beginning of May, some countries, experiencing decreasing numbers of cases and deaths, started lifting confinement measures. However, on 7th May, schools and higher education institutions were still closed in 177 countries, affecting 1268164088 learners, which constitute 72.4\% of total enrolled learners. At almost all higher education institutions that participated in UNESCO survey, COVID-19 affected teaching and learning, only $2 \%$ of those institutions reported that teaching and learning is not affected. It is important to mention that 4 of the 7 higher institutions that reported no effect on teaching and learning are virtual universities. Two-thirds reported that classroom teaching has been replaced by distance teaching and learning and one quarter that most activities are currently suspended but the institution is working on developing solutions to continue teaching and learning, through digital or self- study means. Only $7 \%$ reported that teaching has been cancelled.' (IAU Global Survey Report, 2020). Having all this in mind, it should come as no surprise that teachers had to change their teaching methods in order to suit the needs of their students due to the outbreak of the virus.

What this paper focuses on is how much the replacement of traditional classrooms with online classrooms affects learning English at university level, especially from English language teachers' perspective. The theoretical part of the paper offers a brief overview of traditional and contemporary methods of teaching English before and during the pandemic. The authors presented characteristics of traditional and online classroom, along with the advantages and disadvantages of both approaches, with special reference to the role of teachers. The second part of the paper refers to the research in the form of a questionnaire given to teachers of English at universities in Serbia and the Republic of Srpska in order to determine how much technology is applied in lectures, how much it affects language acquisition and how much it affects the workload of teachers during the pandemic. Analyzing the questionnaire, the paper reached the answer to the question of whether English language teachers believe that online classrooms can really replace traditional classrooms even after the outbreak of COVID-19. 


\section{LITERATURE REVIEW}

\subsection{Teaching English Before the Pandemic}

One of the most common theoretical approaches to traditional teaching implies three main educational methods which were separately used in the classroom, but their intertwining occurred in $21^{\text {st }}$ century as a consequence of the needs for changes in educational system around the world. Teacher-centered method empowers students to simply receive the knowledge from their teacher without building their commitment level. The methodology is considered quite unproductive and retaining. Due to that, most lecturers used to practice the student-centered approach to encourage interest, analytical research, critical thinking and enjoyment among students. However, what is most commonly used today is teacherstudent interactive method, in which we can see the characteristics of both teacher- centered and student- centered method. This teaching method is the best-known technique and it applies the procedures utilized by both teacher and students. The lesson information is recollected in a way that is better than when similar data are introduced to students by the language teacher only. Therefore, research evidence on the lecturing methods maintains that this teaching approach is effective in enhancing students' academic performance (Ganyaupfu, 2013: 29-30).

When it comes to students' behavior in traditional classroom, according to previous studies, it is believed that second language acquisition can be affected by several factors, which are usually divided into three groups: cognitive variables, affective variables and miscellaneous factors such as age, gender or socio/cultural experiences (Bošković Marković, Stanišić, Veljković Michos, 2020: 2 ). All of these factors can be quite extreme in a traditional classroom, but they can be neglected in an online classroom.

\subsection{Characteristics of a Traditional Teacher}

Traditional teacher is the host of the class and their method of addressing is depicted as a pen and paper technique, having in mind that the exercises are prepared and written for students who are then obliged to record the materials utilizing their fundamental school supplies, for instance, a pen and a piece of paper. According to Đorđević, 'Students should not be instructed to learn grammar rules, but rather taught how to 
understand and acquire the meanings conveyed by grammar forms and how to use them in communication' (Đorđević, 2016: 361). That is one of the reasons why traditional teachers use a wide range of techniques in the classroom in order to introduce and clarify study material. Numerous teachers are in favor of direct method as the principle technique in classroom, as numerous studies demonstrate that speaking and listening a foreign language help students learn it in a better way. Also, traditional teachers read a lot of dictations and the grammar translation method is quite common, and students are expected to learn their vocabulary list by heart and memorize the grammar rules (Shoebottom, 2001).

\subsection{Advantages and Disadvantages of a Traditional Classroom/ Teacher}

Traditional classroom offers a wide range of projects and student interaction. Consequently, students can share not only the knowledge they have acquired, but all their questions and concerns regarding the study material as well. Moreover, attending lectures implies following and respecting the university schedule, which provides students with necessary punctuality and a sense of order. This leads to the next important advantage of a traditional classroom and a teacher: discipline, as students have a fixed timetable and fixed hours dedicated only to learning English, without being able to organize some other activities at the same time. Additionally, studying in a group with their peers, students are more motivated, as they all have similar goals (e.g. to pass the exam, learn new vocabulary etc.).

On the other hand, traditional teaching is quite often one- way communication during which teachers talk, and students learn. Discussions, exercises and activities among students are not that usual, usually to the lack of time given for these activities in the curriculum, and lectures are often considered tiresome and monotonous. Considering that traditional examinations have guided teaching; the traditional methods emphasize reading, grammar rules, definitions and memorizing vocabulary. Traditional teaching is also known as question and answer class, where teacher asks the questions and chooses a student to answer, while the rest of the class is indifferent. Less than twenty percent of traditional lecturing is dedicated to language production and the lack of creation, interaction, and critical thinking (Wang, 2007: 28-29). According to another study, more than half 
of interviewed students said that they prefer a workbook and a textbook which is a form of traditional language teaching. Furthermore, the study has shown that the vast majority of students could imagine themselves studying in traditional classrooms without the use of modern technology. They pointed out that traditional approaches of teachers' lectures are far more effective than the use of ICT (Information and Communication Technology) tools for language learning (Veljković Michos, Nasradin, Bošković Marković, 2019: 628-629).

\subsection{Teaching English During the Pandemic}

Throughout the last decade, e-teaching has developed as a permanent solution to teaching; it can be defined as technology-based teaching in which lesson materials are delivered electronically to remote students via a computer network (Zhang et al, 2004: 75). Furthermore, Hiltz \& Turoff (2006) found that 'online teaching is a new social process that is beginning to act as a complete substitute for both distance learning and the traditional face-to-face class. This is because it is also a process that will infiltrate the ordinary face-to-face class and radically change the nature of what is thought of as the typical college course. Face-to-face courses skillfully blended with online learning technologies and methodologies are generally rated by students as significant improvements over traditional face-to-face (only) classes' (Hiltz \& Turoff, 2006: 60).

Some of the most used online classrooms today are Google meet, Microsoft Teams, Zoom and Skype, and all of them are designed in a way that offers students an approximate feeling of a traditional classroom. Google meet is a video conferencing application which is the businessoriented version of Google's Hangouts platform and is suitable for businesses of all sizes. The solution enables users to make video calls with up to 30 users per high-definition video meeting. The application allows users to join pre-scheduled meetings from calendar events, choose a link, enter meeting code and even dial in from their phones if the invitation includes a phone number. Google Meet integrates with G Suite versions of Google Calendar and Gmail and shows the complete list of participants and scheduled meetings. It shows a "join" button for users to connect to the meeting and provides options to mute and turn off the video during the meeting (taken from: https://www.softwareadvice.com/videoconferencing/google-meet-profile/). 
Compared to Google meet, Microsoft Teams is defined as the new chat-based workspace in Office 365. It is naturally integrated with the familiar Office applications and is built from the ground up on the Office 365 global, secure cloud. It also provides chatting, video meetings and documents sharing, along with the option to form groups within the same meeting where users can discuss and share documents. This platform can host up to 10000 users within one online meeting and students can join the class via phone, which is favorable for those who do not own a laptop or a computer (taken from: https://www.microsoft.com/en-us/ microsoft-365/blog/2016/11/02/introducing-microsoft-teams-the-chatbased-workspace-in-office-365/). Zoom is another video communication platform that is popular due to its simplicity and the fact that it is available to everyone. The only drawback of this platform is the length of the meeting: if there are more than two users who are online, the class is limited to 40 minutes. Skype is an online tool that has already been quite popular before the pandemic, as it enables users to receive messages, voice recordings and video calls. However, Skype is not as used as the aforementioned platforms by educational institutions for obvious reasons, one of the most important being the fact that it does not depict a classroom as some of the other applications do.

\subsection{Characteristics of an Online Teacher}

Online teachers are more accountable for the production of their class materials and for the overall design of their classes, as they are quite often recorded and replayed by their students, or by the university management. Moreover, in online settings, English teachers often have limited access to textbooks or their digital version due to the copyright issues. However, many resources are becoming available to lecturers and many of them are allowed to use such textbooks, especially after the outbreak of the pandemic. It is suggested that the design and development of interactive materials with the latest technology and the organization of teaching tools for independent research are required skills for teachers in their list of teacher abilities in distance education (İşman, 2013).

Needless to say, all online teachers need to be computer literate and able to use all applications and technological tools successfully, especially due to the fact that they spend a lot of time posting and checking homework, correcting their students' papers, giving them various online activities 
via different platforms, etc. Furthermore, online teachers are expected to attend their online class on a daily basis, and answer to students' doubts and questions immediately. They should also be able to help students with certain technical problems, including joining classes, submitting assignments and viewing online grades.

\subsection{Advantages and Disadvantages of an Online Classroom/ Teacher}

Students are often not concentrated enough or unwilling to follow the whole lecture in a traditional classroom. However, the usage of video and other prerecorded media puts online classes under the control of students: they are able to watch, rewind, and fast-forward when needed. Online lessons can be viewed more than once, which may help someone who has a problem with language acquisition. According to many studies, flexibility is one of the greatest advantages of online teaching and learning. Both teacher and students can create an atmosphere at home which will make them feel more comfortable. Apart from this, it has been said that online teaching helps teachers balance their workload and private life, which is also crucial, especial for those teachers who have families with children. Students do not need to participate face-to-face in a physical classroom; their attendance is rather checked by teachers through responses to e-mails, discussion class postings and assignment submissions. Also, teachers can follow all the students' improvements and they can easily discern who actually fulfills the assigned activities by giving them online assignments. It has been observed that online classes are especially supported by introverted students, those who are usually quiet and inactive in a traditional classroom (Lowe, 2020).

On the other hand, internet accessibility, student motivation and fair testing of students are clearly some of the disadvantages of online classroom, according to IAU Regional/National Perspectives on the Impact of COVID-19 on Higher Education (August, 2020). Another disadvantage is that students spend all of their 'school' time in front of a computer screen, which adds the time students spend sitting and does not help them get up and get away from their laptops, television and mobile phones (Shi-Chun, Ze-Tian, \& Yi, 2014).

According to a study about online teaching from 2004, 'online teaching requires more maturity and self-discipline from students than 
traditional teaching. There are also logistical concerns about online teaching. For instance, teaching on the Internet involves much more preparation time than in-classroom lecturing. Furthermore, certain types of lesson materials may be too difficult or too costly to be taught online. Other important issues of online teaching must also be taken into consideration. Issues of confidence, authorization, confidentiality, and individual responsibility must be resolved. Owners of intellectual property should be properly compensated. Internet security is a growing challenge, primarily due to the unrestricted access by the public to this universal network. Additionally, since multimedia materials are heavily used in online teaching systems, a high-bandwidth network is a basic requirement for efficient content access' (Zhang et al, 2004: 79).

Additionally, many students seem to think that online classes are not as rigorous as traditional classes and that they are not obliged to spend as much time as they have to spend in the classroom, when these classes actually demand more self-discipline, motivation to work and time management.

\section{RESEARCH METHODOLOGY}

The study, which is a part of a master thesis with a similar topic, begins from the general idea that the increasingly widespread usage of online classrooms has an inferior impact on the proper language acquisition, students' self-confidence in its use, and their social interaction. However, the usage of online classroom elements within traditional classroom provides great benefits to both professors and students, especially in contemporary society. Bearing in mind current trends in language teaching, three hypotheses have been created:

H1: The usage of traditional classroom is more beneficial than the usage of online classroom regarding the achievement of the four main language skills: reading, writing, speaking and listening.

$\mathrm{H} 2$ : The usage of technology in traditional classrooms grants a variety of opportunities for language acquisition in an easier and more diverse way.

H3: Once the pandemic is over, English language teachers will prefer teaching in traditional classrooms to teaching online.

In order to test these hypotheses, quantitative analysis has been used, and an online, anonymous questionnaire was completed by 52 
English language teachers from universities in Serbia and the Republic of Srpska. The first part of the survey offers questions related to the usage of the Internet within the traditional classrooms, its contribution to English language teaching and university English teachers' perspective. The second part gives us the results of the experiences of university English teachers regarding the practice of online teaching during the pandemic, its advantages and disadvantages compared to traditional learning. In the third part we will present the teachers' opinion about whether traditional classrooms can be replaced by online classrooms after the pandemic and to what extent it affects students.

The questionnaire consisted of 14 both open-ended and closeended questions in which respondents had the opportunity to choose one answer or more, share their experiences and leave their comments. The questions were based on the theoretical overview presented in the paper, and the most relevant questions and answers are presented in chapter 4 . The research was mainly conducted at the faculties in the Republic of Srpska and Serbia, and most of the respondents were from Bijeljina and Belgrade. Data collection lasted a month and the survey was delivered to English language teachers by e-mail or by personal contact. Quantitative analysis is used to question the theories, assumptions and hypotheses presented in this paper. In order to achieve a detailed analysis, the answers of the respondents will be presented through tables and graphics. The questionnaire is also added in the appendix.

\section{RESULTS AND DISCUSSION}

It has already been highlighted in the initial part of this paper that the development of the Internet and its use have changed the acquisition of the English language and the way university English teachers organize their lectures. These claims were confirmed when respondents were asked if they think that using the Internet makes it easier to learn English, as most of the respondents (98\%) gave a positive answer, while only one person answered no (1.9\%). Moreover, $9.6 \%$ of university English language teachers answered that they never use technology in their lectures, $36.50 \%$ answered that they use technology all the time, while the highest percentage $(53.80 \%)$ belongs to those who only sometimes use technology in their lectures. Based on these results, we can conclude 
that online teaching is mostly practiced, which indicates that language classrooms are more technologically equipped than before. It can be said that language teachers are increasingly realizing that technologies combined with traditional methods enable teachers to be more practical throughout the teaching process.

When asked whether they think that the four main English language skills (reading, writing, listening and speaking) can be acquired through online classes, $5.8 \%$ of teachers do not think that this is true, $30.8 \%$ think that all of the four skills can be acquired and $63.5 \%$ think that only some of them can be acquired. We can see that more than half of the respondents believe that online classrooms cannot meet the conditions required for the acquisition of all four English language skills. The answers to this question coincide with the answers to the previous question, which leads us to the conclusion that the vast majority of university English language teachers consider the Internet and technology to be an important characteristic of this period and that the contribution of technology is meaningful in language teaching. However, the answers also show us that the opinion of university teachers is that traditional classroom cannot be completely replaced for a quality language acquisition.

The following set of questions relate to the experiences of university teachers during lectures in online classrooms. According to the answers of teachers who sometimes have difficulties during online classes and those who do not have any, it can be assumed that a large number of teachers are digitally literate and that the difficulties they sometimes experience are technical problems such as network connection.

Due to the fact that there have been many answers and comments in the questionnaire, only those which gave specific results regarding testing the hypotheses will be presented in figures, whereas other results will be described in further paragraphs.

When it comes to the question 'What have been the main challenges for teachers in switching to online teaching?' the results show that all teachers had some challenges. The results show that almost all respondents had problem with students' engagement during online classes, which is something that has already been mentioned in the theoretical overview of this paper and it has now been confirmed. Also, students do not take online classes as seriously as traditional classrooms and, according to 38.5 $\%$ of teachers, some of the students do not own a computer or a laptop and are enabled to access the class. Furthermore, another big challenge 
is preparing content for online teaching, which is more demanding than preparing content for traditional classroom. (Figure 1).

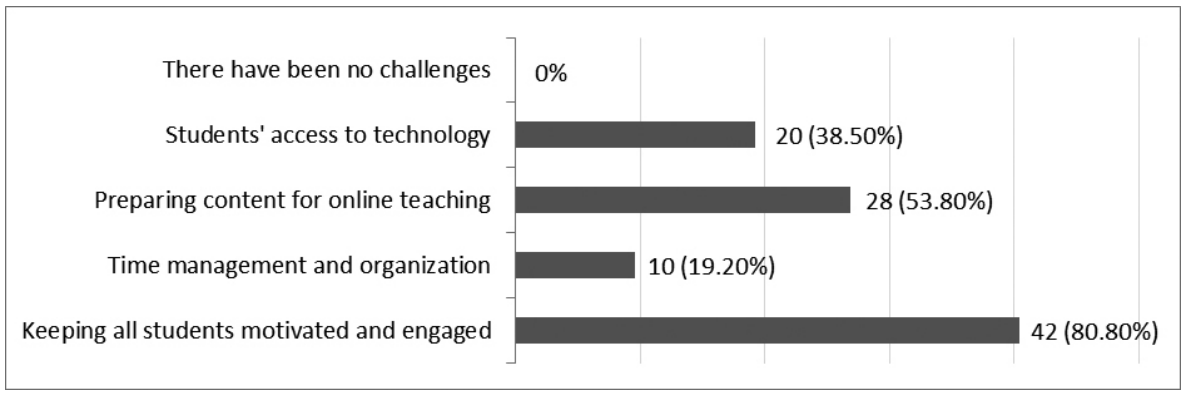

(Figure 1) Graphic presentation of the answer to question no. 5 from the questionnaire: What have been the main challenges for teachers in switching to online teaching?

English language teachers who participated in this study were also asked about their opinion regarding online teaching functionality: $9.2 \%$ said that were surprised by the engagement of students as they were more active than it was expected. The majority of teachers (46.2 $\%$ ) were pleasantly surprised by a wide range of tools, as there are many options that help teachers organize their lectures, such as presenting the PowerPoint presentation while speaking, forms created especially for grading students and effortless ways of posting assignments. It can be concluded that online platforms are designed to provide good functionality, although none of the respondents mentioned its impact on language acquisition. (Figure 2)

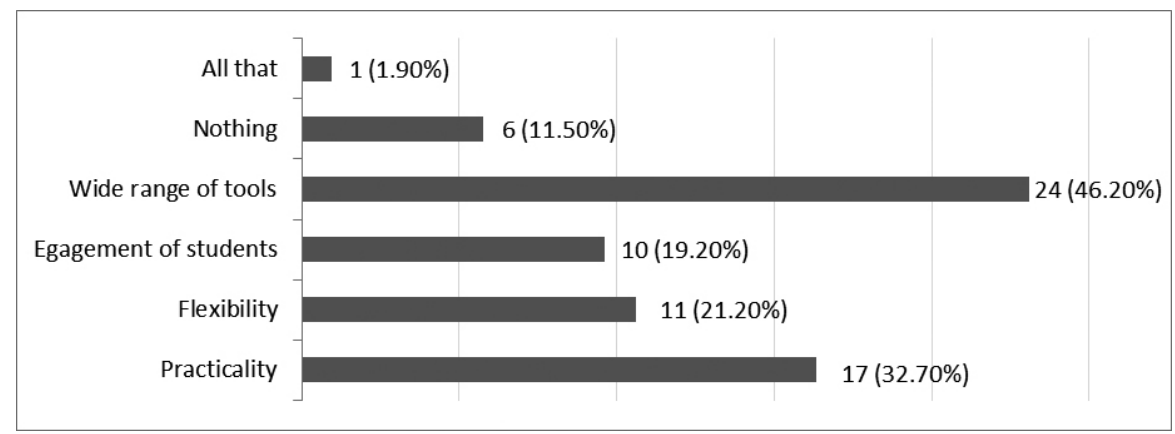

(Figure 2) Graphic presentation of the answer to question no. 6 from the questionnaire: As a teacher, or on behalf of a teacher you know, what has pleasantly surprised you about online teaching/ learning? 
One of the most important questions related to the topic of this paper was: How was your experience teaching students from home as compared to teaching at school? Analyzing the results, $9.6 \%$ of university teachers responded that they don't have an answer to this question, 26.9\% confirmed that their online teaching experience was better compared to teaching at school and as many as $63.5 \%$ said that their online experience was worse. In other words, more than half of teachers prefer traditional classrooms.

Having in mind the theoretical overview of online and traditional teaching, the authors also wanted to check how important face-to-face communication while teaching remotely is. The question was openended and there were two offered answers: Extremely important and not that important. Apart from choosing between these two answers, five university teachers left their own comments which are included in Figure 3. According to these results, we can conclude that face-to-face communication is one the most important features of language teaching. (Figure 3)

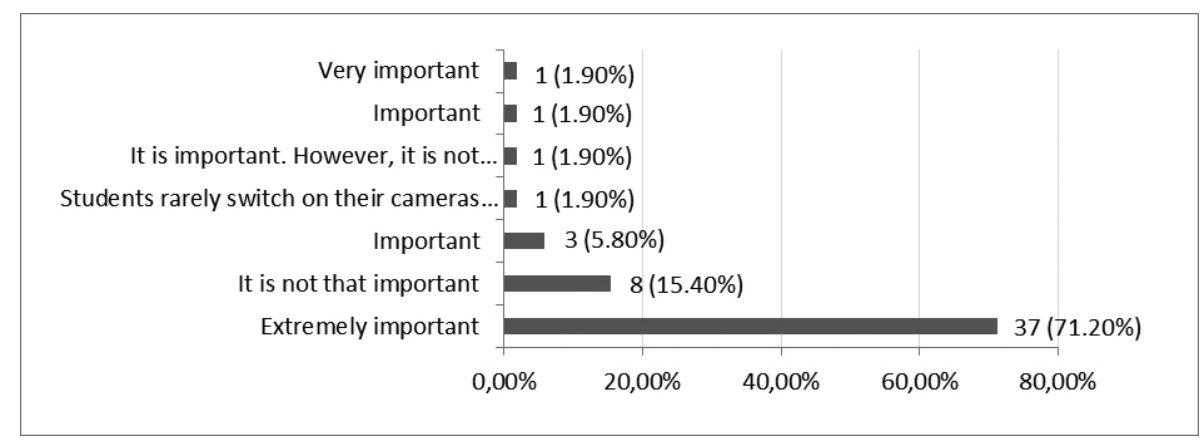

(Figure 3) Graphic presentation of the answer to question no. 11 from the questionnaire: How important is face-to-face communication for you while teaching remotely?

Following the previous question, university teachers expressed their opinion about general feeling concerning online teaching: Are you enjoying teaching your students remotely? The question was openended, but the majority of respondents decided to answer with the one of the two offered: yes or no, while three of them left their own comments. Analyzing the results, $44.2 \%$ said that they are not enjoying teaching their students remotely and $50 \%$ said that they are. One respondent said that he/she is not enjoying teaching remotely too much; another comment 
relates to the fact that students cannot be seen, only the teacher can see them, which we can connect with the previous question where we proved that face-to-face teaching is extremely important for second language acquisition. The third comment belongs to respondent who expressed that he/she missed students' gestures and their communication among themselves.

In order to determine the effectiveness of the current teaching approach due to the pandemic, we have asked university teachers whether online teaching should remain part of university practice after the pandemic. This question was also open-ended and teachers had the option to leave their own comments. $40.4 \%$ of university teachers said that online teaching should not remain part of university practice, whereas $48.1 \%$ said that it should. Along with related comments, six university professors expressed their opinions: [1] Yes, but occasionally; [2] Study materials should be available online; [3] Where applicable, e.g. short tests they cannot cheat on; [4] Sometimes, only for posting online materials; [5] Only for posting online materials, not lecturing and [6] No, it compromises the acquired knowledge. According to these comments, online teaching should not remain regular practice at universities, but it should be used to provide students with necessary material.

The final question regarding the impact of online teaching on students was Do you think that online learning has negative or positive influence on students' social skills? The question was both close-ended and open-ended, as respondents had the option to choose between positive and negative influence, but also to leave their own comments, which can be seen in Figure 4 . As we can see, $23.1 \%$ of teachers said that online teaching has positive influence on students' social skills and $67.3 \%$ said that it has negative influence on students. (Figure 4)

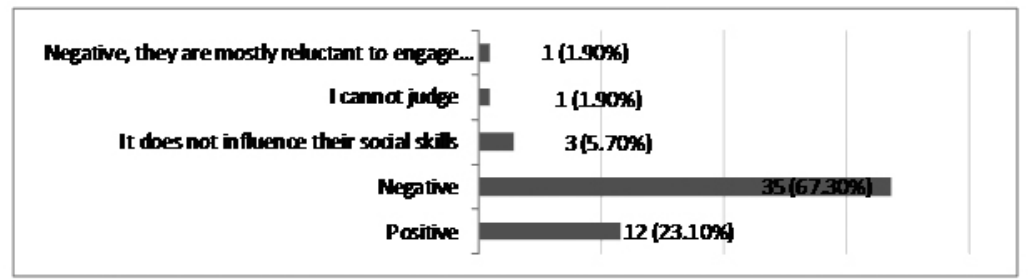

(Figure 4) Graphic presentation of the answer to question no. 13 from the questionnaire: Do you think that online learning has negative or positive influence on students' social skills? 
Analyzing the results of these questions, we can agree that a large number of examined university teachers are more attached to traditional learning. Although online classrooms provide a wide range of tools as well as functionality, teachers find face-to-face teaching more convenient for both them and the students.

After completing the analyses of the results from the questionnaire in which we presented the opinions and attitudes of university teachers regarding the influence of online classrooms on students' social skills; moreover, relying on the answers with the highest percentage, we can conclude that all three hypotheses have been proved: The usage of technology in traditional classrooms grants a variety of opportunities for language acquisition in an easier and more diverse way, the usage of traditional classroom is more beneficial than the usage of online classroom regarding the achievement of the four main language skills: reading, writing, speaking and listening, and, most importantly, once the pandemic is over, English language teachers will prefer teaching in traditional classrooms to teaching online.

\section{CONCLUSION}

Having in mind that the integration of ICT in educational process should rely on teachers' pedagogically grounded and responsible use with clear educational goals, the real impact on teaching practice, the relevance for the objective needs and interests of, teachers should undoubtedly keep the leading role in education, despite all technological advancements students (Veljković Michos, Bošković Marković, 2020). As it has been shown in the results of this study, these technological advancements are accepted by university teachers to the extent that the majority of them see benefits in using them for language acquisition, but they also share the opinion that traditional classrooms cannot be completely replaced by technology. In other words, university teachers are fully aware of the fact that the usage of technology within a traditional classroom enables them to teach a foreign language in a more interesting way and to sometimes motivate their students more. However, they still find traditional classrooms more favorable and effective not only for teaching, but for students' behavior and knowledge as well. Moreover, language teachers see face-to-face communication as an extremely important segment 
of teaching and learning, and that is something that online classrooms usually cannot offer.

According to the research presented in this paper, more than half of the respondents agree that online teaching should not be the only part of university practice once the pandemic is over, but that it should only be used occasionally for posting online materials or additional exercises. Therefore, we may conclude that teaching in online classroom in the future should not be the only option for language teachers, but a matter of choice and decision based on the needs of both language teachers and their students.

\section{References}

Bošković Marković, V, Stanišić, N, Veljković Michos, M. (2020). Is English a male language and Spanish a female language? An explorative study of gender and second language acquisition at a higher education institution in Serbia, Komunikacija i kultura, Vol. 2020, No. 11, pp. 1-28.

Chhabra, P. (2012). Use of E-Learning tools in teaching English. International Journal of Computing \& Business Research, 3, 22296166.

Đorđević, J. (2016). English language teaching methodology in a CALL classroom: Testing and evaluating traditional grammar instruction. Nastava $i$ vaspitanje, $65,359-378$.

Ganyaupfu, E. M. (2013). Teaching methods and students' academic performance. International Journal of Humanities and Social Science Invention, 2(9), 29-35.

Hiltz, S. R., \& Turoff, M. (2005). Education goes digital: The evolution of online learning and the revolution in higher education. Communications of the $A C M, 48(10), 59-64$.

IAU Global Survey Report, Published by the International Association of Universities, May 2020, UNESCO, France https://www.iau-aiu.net/IMG/ pdf/iau_covid19_and_he_survey_report_final_may_2020.pdf, retrieved on 13th February, 2021

IAU Regional/National Perspectives on the Impact of COVID-19 on Higher Education, August 2020, UNESCO, France https://www.iau-aiu.net/ IMG/pdf/iau_covid-19_regional_perspectives_on_the_impact_of_covid-19 on_he_july_2020_pdf, retrieved on 13th February, 2021 
İşman, A, Aydin, C. H, Kiyici, M. (2013). Introduction to The Online Journal of Distance Education and e-Learning, 1(2).

Lowe, J. (2020, June 5). Attendance in Online Classes Versus Traditional Classrooms. Classroom.Synonym. https://classroom.synonym.com/attendanceonline-classes-versus-traditional-classrooms-1725.html, retrieved on 20th December, 2020

Shoebottom, P. (2001). Language teaching methodologies. Frankfurt International School. http://esl.fis.edu/teachers/support/method.htm, retrieved on 15th December, 2020

Veljkovic Michos, M, Boskovic Markovic, V (2020). 'Teachers' perception of the use of ICT in foreign language teaching in a higher education institution', In Sinteza 2020-International Scientific Conference on Information Technology and Data Related Research, pp. 93-98.

Veljković Michos, M, Bošković Marković, V, Nasradin, K. (2019). Traditional Language Teaching Versus ICT Oriented Classroom. In Sinteza 2019-International Scientific Conference on Information Technology and Data Related Research (pp. 627-632). Singidunum University.

Wang, T. P. (2007). The comparison of the difficulties between cooperative learning and traditional teaching methods in college English teachers. The Journal of Human Resource and Adult Learning, 3(2), 23-30.

Zhang, D et al. (2004). Can e-learning replace classroom learning? Communications of the ACM, 47(5), 75-79.

\section{Dragana Ilić, Valentina Bošković Marković}

\section{ONLAJN NASTAVA IZ PERSPEKTIVE PREDAVAČA ENGLESKOG JEZIKA}

Sažetak: Predmet ovog rada je analiza uticaja upotrebe onlajn nastave kao zamene za tradicionalnu učionicu u nastavi engleskog jezika na univerzitetskom nivou sa aspekta profesora engleskog jezika. Rad nudi pregled osnovnih karakteristika tradicionalne i onlajn učionice, uz predstavljanje prednosti i mana oba pristupa, sa posebnim osvrtom na ulogu profesora. Istraživanje koje je predstavljeno u radu zasnovano je na analizi onlajn upitnika kako bi se došlo do zaključka da li profesori engleskog jezika smatraju da onlajn učionice zaista mogu da zamene tradicionalnu nastavu i nakon pandemije.

Ključne reči: tradicionalna učionica, onlajn nastava, engleski jezik, pandemija 


\section{APPENDIX}

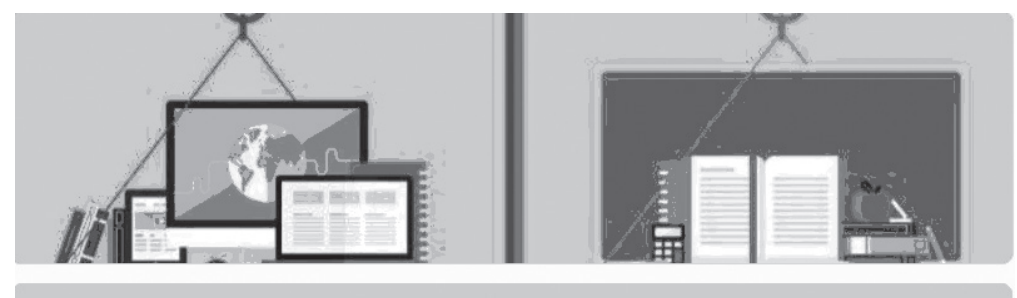

\section{Survey: Traditional vs Online teaching}

Thank you for your time!

* Required

1. Do you think that using the Internet makes it easier to learn English? *

$\bigcirc$ Yes

$\bigcirc$ No

2. How often do you use technology in your lectures (powerpoint, youtube videos, online quizzes etc.)?

All the time

Sometimes

$\bigcirc$ Never

N/A

3. Do you think that the four main English language skills (reading, writing, listening and speaking) can be acquired through online classes? *

Yes, all of them

Some of them

No

Other: 
4. Do you have any difficulties using the technology during online classes? *

$\bigcirc$ Yes

sometimes

No

N/A

5. What have been the main challenges for teachers in switching to online teaching?*

$\square$ Keeping all students motivated and engaged

$\square$ Time management and organization

$\square$ Preparing content for online teaching

Students' access to technology

There have been no challenges

Other:

6. As a teacher, or on behalf of a teacher you know, what has pleasantly surprised you about online teaching/ learning? *

$\square$ Practicality

$\square$ Flexibility

$\square$ Engagement of students

$\square$ Wide range of tools

Nothing

$\square$ Other:

7. How was your experience teaching students from home as compared to teaching at school? *

Better

Worse

$\bigcirc \mathrm{N} / \mathrm{A}$ 
8. Have you noticed that students acquire less knowledge through online classes than through the traditional way? *

Yes, I have

No, I haven't

Other:

9. What kind of response have you got so far from your students? *

Positive, most students engage during online classes

Negative

Other:

10. Do you think that students are equally motivated to work in the online classroom as much as they are in the traditional classroom? *

$\bigcirc$ Yes

No

Other:

11. How important is face-to-face communication for you while teaching remotely? *

Extremely important

It is not that important

Other: 
12. Are you enjoying teaching your students remotely? *

Yes

No

Other:

13. Do you think that online learning has negative or positive influence on students' social skills? *
Positive
Negative
Other:

14. In your view, due to the current situation created by the COVID-19 pandemic, when schools fully reopen, should online teaching remain part of university practice? *
Yes, definitely
$\bigcirc$ No
Other: 